\title{
Innovative Prospects for Suicide Prevention and Action Opportunities for the Public Health Agency of Canada and the Government of Canada
}

[La version française suit.]

\author{
Alain Lesage \\ Institut universitaire en santé mentale de Montréal \\ Christophe Tra \\ Université de Montréal \\ Elham Rahme \\ McGill University \\ Johanne Renaud \\ Douglas Mental Health University Institute \\ Lise Thibodeau \\ McGill University \\ Monique Séguin \\ Université du Québec en Outaouais
}

Alain Lesage, researcher, Research Centre, Institut universitaire en santé mentale de Montréal, and professor, Department of Psychiatry, Université de Montréal; Christophe Tra, Université de Montréal; Elham Rahme, Department of Medicine, Division of Clinical Epidemiology, McGill University; Johanne Renaud, researcher, Manulife Centre for Breakthroughs in Teen Depression and Suicide Prevention, Douglas Mental Health University Institute, and associate professor, Department of Psychiatry, McGill University; Lise Thibodeau, Department of Medicine, Division of Clinical Epidemiology, McGill University; Monique Séguin, professor, Department of Psychoeducation and Psychology, Université du Québec en Outaouais.

Correspondence concerning this paper should be addressed to Alain Lesage, Institut universitaire en santé mentale de Montréal, 7401 Hochelaga Street, Montreal, QC H1N 3M5; email: alesage.iusmm@ssss.gouv.qc.ca. 


\begin{abstract}
Responsibility for suicide prevention falls to the Government of Canada and Health Canada. The issue of suicide affects Canadians of all ages and in all regions of the country, hence the need for a panCanadian strategy aimed at reducing suicide deaths and reaching all Canadians. The availability and accessibility of mental health services constitute important resources for suicide prevention and a target for interventions that can be made to rapidly reduce the suicide rate. Such a strategy to improve services should include quality surveillance and quality control programs, such as suicide audits and the use of linked government administrative databases. Population-based strategies to prevent and treat depression must also be established and should be based on the Nuremberg model. In particular, development of equitable access to psychotherapy and mental health literacy programs should be priority goals.
\end{abstract}

Keywords: suicide prevention, addictions, depression, relationship problems, mental health and addiction services, quality of services, administrative health databases, chronic disease surveillance system, suicide audits

\title{
RÉSUMÉ
}

La prévention du suicide est la responsabilité du Gouvernement du Canada et de Santé Canada. Au Canada, la problématique du suicide touche les Canadiens et Canadiennes de tout âge et de toutes les régions du pays, d'où la nécessité d'une stratégie pancanadienne visant la réduction des décès par suicide et touchant tous les Canadiens et Canadiennes. La disponibilité et l'accessibilité des services de santé mentale sont des ressources importantes pour la prévention du suicide et une cible sur laquelle des interventions peuvent être posées pour une réduction rapide du taux de suicide. Une telle stratégie misant sur l'amélioration des services devrait inclure la mise en place de programmes de surveillance et de contrôle de qualité, tels que des programmes d'audits des cas de suicides et l'exploitation des bases de données administratives jumelées gouvernementales. Des stratégies populationnelles de prévention et de traitement de la dépression sont aussi à instaurer, et devraient se baser sur le modèle de Nuremberg. Nous retenons particulièrement prioritaires comme stratégies populationnelles la mise en place de programmes d'accès équitable à la psychothérapie et de littératie en santé mentale.

Mots clés : prévention du suicide, dépendances, dépression, troubles relationnels, services santé mentale et des dépendances, qualité des services, bases de données administratives de santé, système de surveillance des maladies chroniques, audits des suicides

In Canada, mental health is a topical political issue at both provincial and federal levels. Canadian political leaders call on everyone to invest in mental health, making suicide prevention a top priority. However, this political will must be translated into a clear and pragmatic action plan, and this process will inevitably involve public health initiatives. In this article, we seek to present innovative public health options for suicide prevention and propose roles for health services and actions that the Public Health Agency of Canada and the Minister of Health could undertake.

First, we outline the state of suicide in Canada. The data presented demonstrate that suicide affects all age groups and regions in the country. With this in mind, we postulate the need for a Canadian suicide prevention strategy that targets all Canadians, not just high-risk groups. Second, we describe conceptual models for understanding suicide from an individual and a systemic point of view. Analyzing these models allows us 
to identify priority target services for any national suicide prevention strategy. Third, supported by recent literature and more than 30 years of experience in mental health services research, we propose innovative public health interventions for suicide prevention: (a) establishing mechanisms for evaluating services based on a bottom-up approach, (b) improving top-down surveillance systems through the use of chronic disease surveillance systems, and (c) more in-depth assessment or implementation of suicide prevention strategies at the population level, including mental health literacy programs and increased access to psychotherapy.

\section{A SILENT EPIDEMIC THAT TOUCHES ALL CANADIANS}

In Canada in the early 21 st century, 10 people die by suicide every day, nearly 4,000 people per year, at a rate of 10.4 per 100,000 individuals (16.1 for men and 5.1 for women) (Navaneelan, 2009). Men between 30 and 60 years of age account for more than $50 \%$ of suicide cases, and those aged $45-64$ are at highest risk of suicide with rates of almost 25 per 100,000. For young people (15-24), the rate was close to 20 per 100,000, representing more than 200 young Canadians between the ages of 15 and 19 who died by suicide in 2010, or slightly more than 1 in 20 suicides in Canada (Thibodeau, 2015; Navaneelan, 2009). Men are more affected than women by suicide: four times as many men as women take their lives annually (Navaneelan, 2009). Figure 1 shows the number of suicides in Canada by province and territory in 2012. The Northwest Territories, Yukon, and Nunavut, where Indigenous communities are concentrated, account for 42 of the 3,662 cases that occurred in that year. The majority of suicides, however, come from Quebec and Ontario: just over 25\% of the Canadian population lives in Quebec, yet close to one third of all suicides in Canada took place there. If Quebec had had the same suicide rate as Ontario, there would have been 400 fewer suicides in Quebec, and in Canada, in 2008.

Despite this alarming picture, rates of suicide deaths have declined in Canada over the last three decades, especially among men (Thibodeau, 2015). Figure 2 illustrates the decline in rates across all age groups, particularly among teenagers and seniors. In fact, these two groups show the lowest suicide rates in the country according to the most recent data.

These figures show that although the suicide rate is alarming in some well-known subgroups, such as among Indigenous people, the suicide epidemic affects individuals of all ages and all regions in Canada. This suggests the need for a pan-Canadian suicide prevention strategy to help us better understand and prevent suicides in general among Canadians. These numbers also suggest that some strategies at the population level have the potential to reduce suicide rates. 


\section{Figure 1}

\section{Number of Suicides in Canada by Province and Territory, 2012}

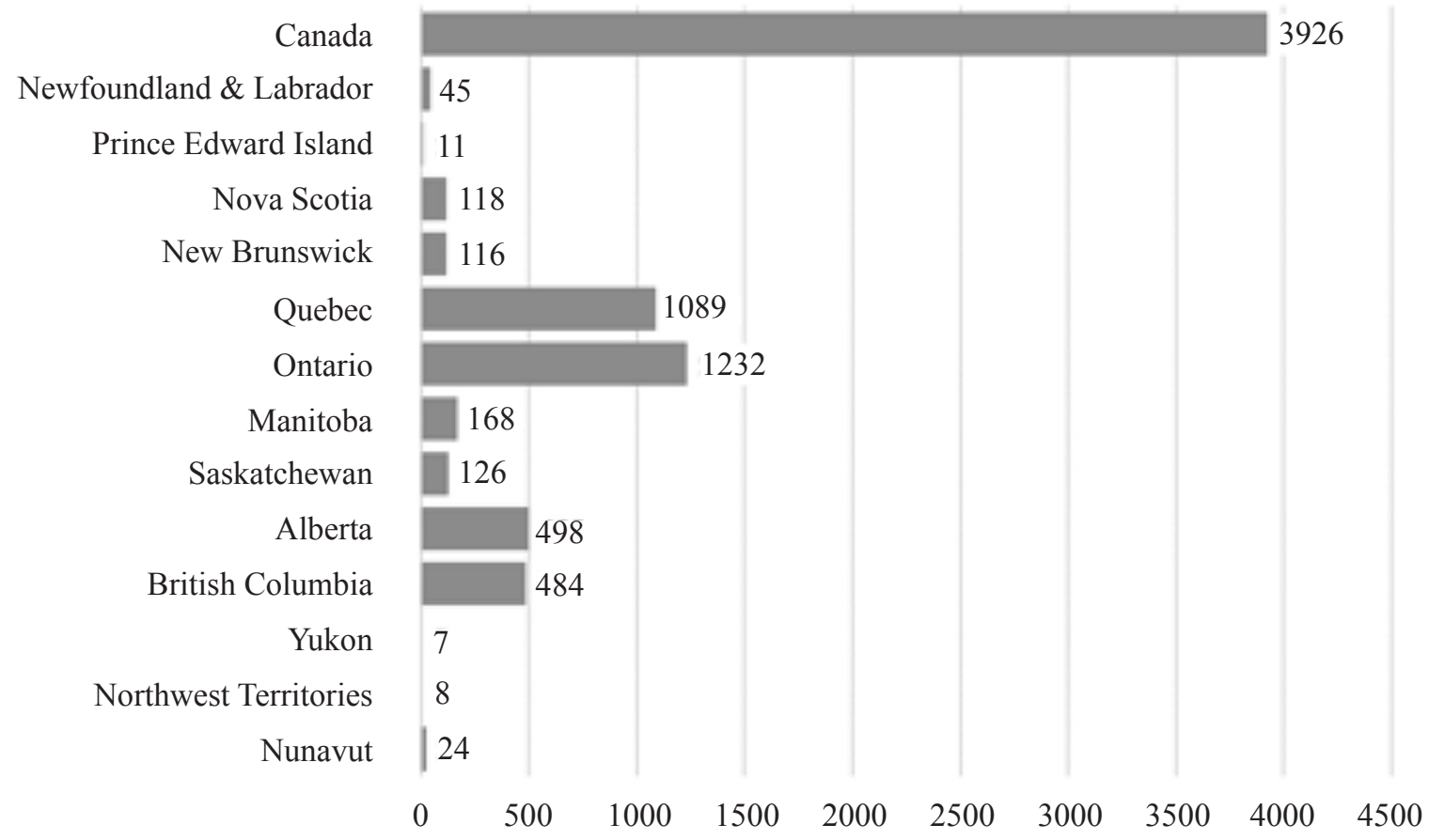

Source: Statistics Canada, Table 102-0563, Leading Causes of Death, Total Population, by Sex, Canada, Provinces and Territories (Age Standardization Using 1991 Population), retrieved from http://www5.statcan.gc.ca/cansim/a05 ?lang=eng\&id=1020563\&retrLang=eng 
Figure 2

Suicide Rate in Canada by Age Group

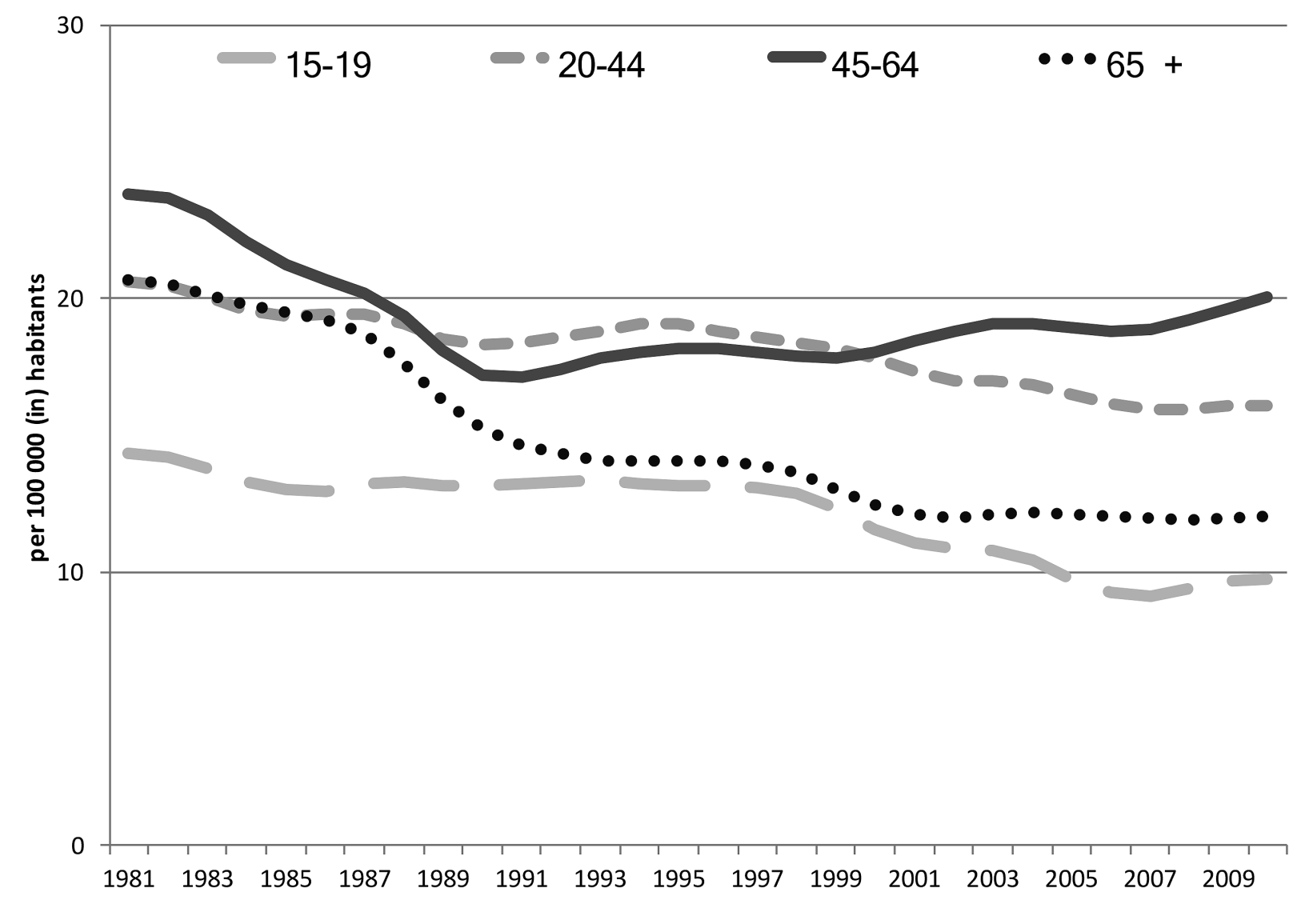

Source: Public Health Agency of Canada, Institut National de Santé Publique du Québec 


\section{INDIVIDUAL AND PUBLIC HEALTH MODELS FOR SUICIDE PREVENTION}

Many theoretical models have been proposed to explain the origins and determinants of suicide. Here are two models for understanding suicide from a public health perspective.

\section{Model of Suicide Caused by Individual Factors Within a Social Context}

The McGill Group for Suicide Studies has proposed a model that examines the individual causes of suicide (McGirr \& Turecki, 2007; Renaud et al., 2015; Turecki \& Brent, 2016), which we have sketched in Figure 3. Factors leading to a predisposition, such as biological and genetic determinants, when further influenced by childhood trauma or adverse life events, may lead to the development of mediating determinants such as impulsivity or personality disorders. This fragility, when combined with the development of mental disorders or substance abuse, can lead to suicide. Note that this process is modulated throughout by factors extrinsic to the person, such as their social determinants. The influence of the social environment makes it possible to understand suicide from a public health perspective.

\section{Public Health Model Based on Quality of Mental Health Care}

This public health perspective is further developed through another model proposed by Lesage, StLaurent, Gagné, and Légaré (2012). It is based on the Institut National de Santé Publique du Québec (INSPQ) model of determinants of health status in populations (Bernard, Lemay, \& Vézina, 2004). The INSPQ model considered four main vectors: (a) genetic and developmental factors, (b) environmental factors (physical or sociocultural), (c) lifestyle, and finally (d) services. This model is graphically represented by the conceptual framework presented in Figure 4, which gives more importance to services than the preceding model as determinants counterbalancing more intrinsic factors such as sex, age, and developmental history.

Based on this model, three levels can be identified at which services can influence suicide: (a) the individual level (e.g., psychotherapy that was not offered); (b) the programmatic level (e.g., insufficient coordination between specialized mental health services and addiction services for people with comorbidities); and (c) the systemic level (for example, an awareness campaign to identify signs of depression or addiction problems in the home or family).

These determinants are added to environmental factors that exist at both the individual and population levels. For example, more macroscopic social environmental factors include the unemployment rate and living in a socially and materially disadvantaged neighbourhood. Such determinants, especially social isolation, were described more than 100 years ago by the founder of modern sociology, Émile Durkheim (1897/1951), in his famous book on suicide. Individual factors also exist at the microsocial environmental level, such as childhood traumas, as discussed by Afifi et al. (Afifi et al., 2008; Afifi et al., 2016) using U.S. and Canadian data. They showed that the etiological fraction attributable to harmful experiences in childhood was $25 \%$ for mental disorders, $20 \%$ for suicidal ideation, and $40 \%$ for suicide attempts.

These two models illustrate the multifactorial origin of suicide and indicate that interventions can be made at several levels, both individual and systemic. However, from the point of view of a national strategy, distal factors in a completed suicide (genetic factors, developmental factors, childhood trauma) are less 
Figure 3

Model of Suicide Caused by Individual Factors Within a Social Context
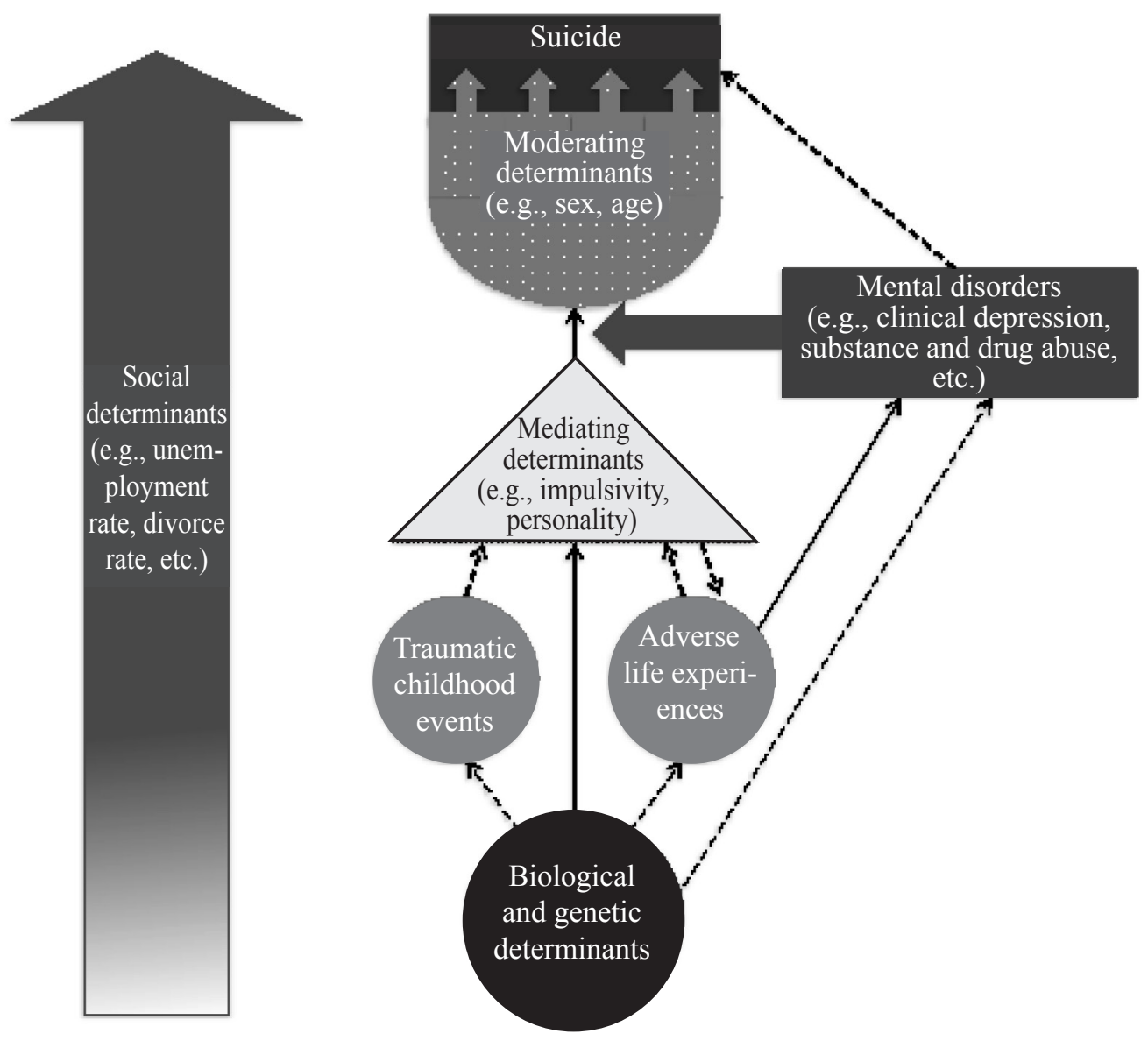


\section{Figure 4}

Public Health Model of the Quality of Mental Health Care as One of the Environmental Determinants of Suicide in the Population

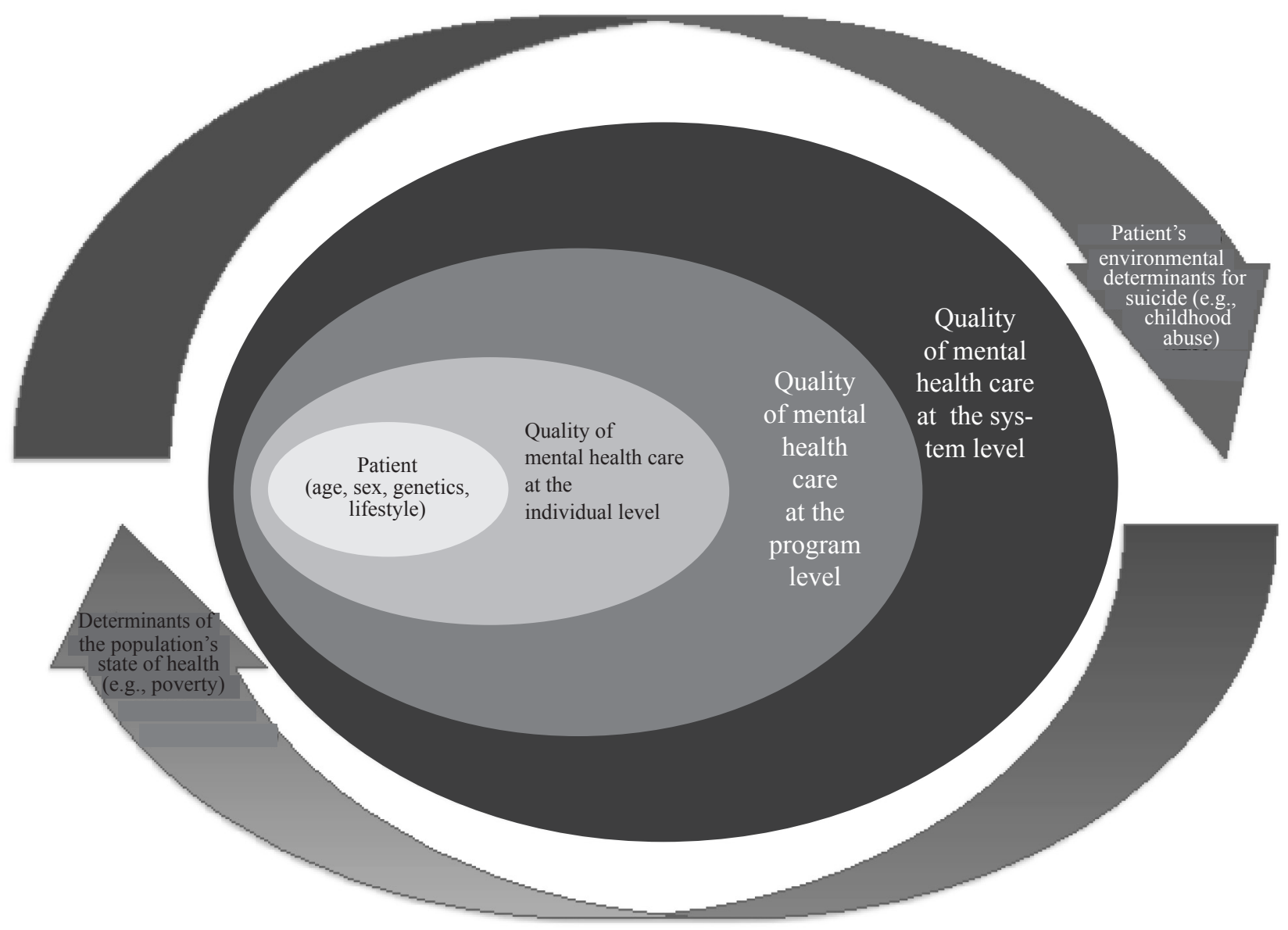


susceptible to public health actions that can lead to a rapid reduction in suicide. More proximal factors, such as quality of care or better coordination between addiction services and mental health teams, could have a more immediate impact on suicide prevention.

\section{INNOVATIVE MONITORING SYSTEMS}

We propose three actions that the Public Health Agency of Canada and the Government of Canada should take in the context of their role in, and responsibility for, suicide prevention (Lesage, Turecki, \& Daniels, 2017):

1. Establishment of service evaluation programs based on a bottom-up approach. We propose here two modalities: audit programs and questionnaires sent systematically to doctors treating patients who died by suicide.

2. Improvement of top-down surveillance through the use of chronic disease surveillance systems, such as the Quebec Integrated Chronic Disease Surveillance System (QICDSS).

3. More in-depth evaluation and even implementation of strategies at the population level, including mental health literacy programs along the lines of the Quebec program Partners for Life (Solidaires pour la vie, now Solidaires pour la santé mentale) and increased access to psychotherapy.

\section{Bottom-Up Approaches: Audits}

Surveillance systems must be enhanced in Canada; more data are needed to evaluate suicide prevention services. A bottom-up approach, auditing, is particularly useful in assessing services' strengths and weaknesses. Such an audit can be based on a range of tools, from a questionnaire sent to the last attending physician to in-depth interviews known by the somewhat offputting name of "psychological autopsies."

Developing a program of systematic questionnaires to be sent to the attending physicians of patients who die from suicide would provide an interesting source of bottom-up information. Such a program has existed in Great Britain since 1996 for patients known to specialist psychiatric services who took their lives, accounting for $25 \%$ of all suicides. The National Inquiry into Suicide and Homicide by People with Mental Illness collects questionnaires sent to professionals responsible for gathering patient data and information about the circumstances surrounding the suicide. Thanks to the continuous survey carried out in Great Britain since 1996 through a quality improvement partnership between the U.K. health system and the academic community, recommendations have been formulated both at the level of regional programs and at the national level. These recommendations, for example setting up 24-hour crisis intervention services or developing policies to manage patients with dual diagnoses, have been implemented in different regions. Regions that implemented the recommendations saw their suicide rates decline (While et al., 2012).

More detailed methods, involving in-depth interviews with bereaved families and a review of available medical records for all suicide cases, were deployed in Canada through government-requested inquiries. For example, in the early 2000s, the New Brunswick government, concerned about the suicide rate in the province, asked the McGill Group for Suicide Studies under the leadership of Dr. Monique Séguin to examine all cases of suicide over the course of a year in New Brunswick (Lesage et al., 2008). 
The New Brunswick study took place in 2003-04, using psychological autopsy and audit methodology. Staff from regional mental health centres were trained to conduct semi-structured interviews with the bereaved families and to review available medical records. Case histories from family interviews and systematic case reviews were analyzed by a panel of psychiatrists, psychologists, representatives from the Addiction and Mental Health Services Branch of the New Brunswick Department of Health, as well as social workers, nurses, and a representative of the bereaved families affected by suicide. Following a reconstruction of the trajectory that each life took, the services used were analyzed and compared with all the services that, according to the panel, should have been offered.

Initially, this innovative approach provided a picture of the life trajectories that led to suicide, and especially profiles of the use of services: mood disorders or addictions were identified in more than two thirds of cases; personality disorders in half; and more than one disorder (comorbidity) in $75 \%$ of the cases (Séguin et al., 2006). On the basis of these results, the panel was then able to identify deficits in available services at several levels. Table 1 compares the gap between interventions received by individuals in their last year of life and the interventions the panel felt were required, as well as the percentage gap, which illustrates possible deficits in services available at the individual level.

While psychiatric medication needs were generally well met, there were gaps when it came to hospitalization, detoxification centre services, and more intensive follow-up. It should be noted that the most widely ignored need was counselling or psychotherapy. The results show that in almost $30 \%$ of cases no recommendations could be made, but that in more than $70 \%$ of cases two major patterns of deficits in programs and the health system emerged. In almost half of these cases, there were unmet needs in the area of social and primary health services, as individuals did not know whom to approach to ask for help. These needs could be met through: population-based campaigns to encourage people to seek counselling for mental health or addiction issues, and more training for family physicians and psychosocial primary care providers in the reception, identification, and treatment of mental disorders and addiction and, if necessary, referral to specialized services.

The second major type of recommendation involved the need for coordination and continuity between specialized mental health services, addiction services, and hospital emergency departments, and sometimes

Table 1

Comparison Between Interventions Received and Interventions Required, and the Percentage Gap

\begin{tabular}{llll}
\hline & Received, $n$ & Required, $n$ & Gap, \% \\
\hline Psychiatric medication & 51 & 65 & 22 \\
Residential / hospital / detox & 38 & 70 & 46 \\
Intensive follow-up & 34 & 71 & 52 \\
Psychotherapy & 19 & 48 & 60 \\
Peer support & 13 & 12 & - \\
\hline
\end{tabular}

Source: Audit of 102 suicide cases in New Brunswick (Lesage et al., 2008). 
collaboration with criminal justice services. These services could have benefited from a more proactive and collaborative approach and close links between these sectors (Lesage et al., 2008).

Using the same approach, case-control studies involving 67 adolescents and young adults were conducted under the direction of Dr. Johanne Renaud (Séguin, Renaud, Lesage, Robert, \& Turecki, 2011, Renaud et al., 2014). In the final year of life, those 14 - to 25 -year-olds who died by suicide were 8 to 63 times more likely to have depressive disorders, anxiety, or substance dependence than young people in the control group. Examination of their life trajectories from birth to age 4 indicated that $50 \%$ of these young people had been exposed to violence or physical or sexual abuse. This rose to $60 \%$ when examining the period between 5 and 9 years old, and $67 \%$ in the period between 10 and 14 . For young people in the control group, the numbers were only $14 \%, 18 \%$, and $34 \%$ respectively.

Two distinct types of suicide trajectories emerged. The first group is characterized by adversity that begins very early in life, associated with developmental and environmental factors that favour vulnerability to the presence of mental disorders. These young people become very well known to professionals in specialized services dealing with youth, mental health issues, and addiction. The second group is characterized by later adversity, associated more with lifestyle and presenting with fewer comorbidities. These patients were therefore more likely to be monitored by primary health and social services. A detailed analysis of the organization of services for these youth also showed significant deficits comparable to those of the New Brunswick study.

In addition, similar risk factors were identified in one study conducted among Inuit (Chachamovich et al., 2015). In that study, interviews were conducted with relatives, allowing the researcher to reconstruct the life trajectory, with special attention to adversity, mental disorders, and traits of impulsivity and aggression. Results show that people who died by suicide were more likely to have suffered physical and sexual abuse in childhood, experienced depression and addiction to alcohol and cannabis, manifested increased traits of impulsivity and aggression, and presented with personality disorders.

Therefore, our recommendation to the Public Health Agency of Canada would be to conduct — as was done in the United Kingdom - a confidential inquiry into all suicide cases, through questionnaires given to the last treating physician, interviews with bereaved family members, or a combination of the two, with a view to identifying options to improve services for all Canadians. Hopefully, following implementation of these recommendations, suicide rates will decline in all Canadian communities, as they did in Great Britain.

\section{Top-Down Approaches: Administrative Databases}

A review of administrative health databases may also reveal deficits. The public health agency in Wales, in collaboration with academic circles, has established a platform for reviewing linked administrative databases bringing together population health data to effectively identify service deficits (John et al., 2014). Canada has a similar system. The Public Health Agency of Canada's Chronic Disease Surveillance System receives aggregate data from each province, which enables it to track the evolution of quality indicators for medical services for mental health purposes. Two reports have already been produced: on mental disorders in general and on mood and anxiety disorders specifically (Public Health Agency of Canada, 2015, 2016). In Quebec, an analysis produced through the Quebec Integrated Chronic Disease Surveillance System (Blais 
Table 2

Use of Medical Services During the Last Year of Life in 12,301 Suicide Cases in Quebec 2000-2009

\begin{tabular}{ll}
\hline For mental health purposes (mental health diagnosis associated with the service): \\
\hline Hospitalization & $14 \%$ \\
Emergency & $27 \%$ \\
Outpatient psychiatrist & $31 \%$ \\
General practitioner in ambulatory care & $45 \%$ \\
No contact for apparent mental health purposes & $47 \%$ \\
\hline All contact with medical services: & \\
\hline Hospitalization & $27 \%$ \\
Emergency & approx. $49 \%$ \\
General practitioner & between $79 \%$ and $86 \%$ \\
Specialist & between $72 \%$ and $76 \%$ \\
No contact & between $12 \%$ and $21 \%$
\end{tabular}

Source: Chronic Diseases and Determinants Surveillance Unit, INSPQ; RAMQ, MeDEcho, Institut de la Statistique du Québec

et al., 2014) examined the use of services in the year before death; the result is presented in Table 2. In the year before their deaths, more than half of the people who died by suicide had attended emergency rooms; $30 \%$ consulted psychiatrists on an outpatient basis; and more than $80 \%$ had consulted family physicians, although only half had been formally diagnosed with a mental disorder or substance addiction during this contact with family doctors.

In a recent publication, using QICDSS data, the Institut National de Santé Publique du Québec demonstrated that individuals with personality disorders have a lower average life expectancy by more than 12 years and that one quarter of those deaths were due to suicide. In addition, these individuals made greater use of emergency and specialized services (Cailhol et al., 2017). These findings, coming from a broad health administrative database, complement those of audits to support the importance of coordination between emergency departments and specialized mental health services for individuals with personality disorders.

Implementation of surveillance tools in the Canadian context - either through physician-based questionnaires or in-depth interviews with families to establish the individuals' life trajectories and unmet needs for services on one hand, or through the analysis of linked administrative databases on the other-represents an innovative opportunity at the national level to better identify service gaps and make targeted recommendations. It is to be hoped that the appropriate programs will be implemented at the provincial and regional levels, as well as in individual practices, with the ultimate outcome of reducing the number of suicide deaths. 


\section{Implementation of Population-Based Suicide Prevention Strategies Through Best-Practices Treatment of Depression}

Bottom-up studies, such as those in New Brunswick, have confirmed the significant portion of the population that experiences depression and the importance of a suicide prevention strategy (Lesage, 2002). The goal is to ensure that (a) the population is able to identify signs and symptoms when a person or a family member is depressed and to seek consultation and (b) that effective treatments are offered in the context of social services and health primary care. The best-known and most extensively studied program of bestpractices population strategies for treating depression was developed in Nuremberg and spread to several European countries (Hegerl, Althaus, Schmidtke, \& Niklewski, 2006; Hegerl et al., 2009). It is based on four strategies: (a) raising public awareness of how to identify depression and of the fact that it can be treated; (b) training family physicians in the detection and therapeutic management of depression and suicide risks; (c) training of front-line psychosocial workers in the detection and therapeutic management of depression and suicide risks; and (d) improving the therapeutic management of people at known risk, such as those presenting in emergencies following a suicide attempt.

This program maintains that it is able to reduce suicide rates by one quarter. Taking into account the Canadian context, a group of researchers modelled the costs and benefits of implementing this program and its four population-based strategies (Vasiliadis et al., 2015). With a potential for suicide reduction of 25\%, the program would be self-financing, costing very little: about $\$ 3$ per capita per year, in the context of a Quebec mental health budget of about $\$ 170$ per capita. The health and social services budget, excluding the payment of doctors and drugs, is $\$ 2,500$ per capita.

Meanwhile, two programs in particular could be rapidly implemented by the federal Department of Health: (a) increased access to psychotherapy under a federal mental health transition fund (Lesage, Bland, et al., 2017) and (b) an evaluation of the Partners for Life mental health literacy program (Lesage \& Moubarac, 2011) with a view towards extending it.

The first is based on acknowledging the enormous counselling deficit, found in $60 \%$ of suicide cases in New Brunswick (see Table 1). Psychotherapy is an effective treatment for depression (Fansi, Jehanno, Lapalme, Drapeau, \& Bouchard, 2016) that would complement the services supplied by the family physicians who would prescribe it. In Canada, more than $12 \%$ of the adult population has expressed a need for therapy, and in a third of cases this need was not met (Sunderland \& Findlay, 2013). In Australia, psychotherapy prescribed by a family physician and conducted by a certified psychologist is reimbursed by the public health insurance system, equivalent to RAMQ in Quebec or OHIP in Ontario (Lesage, Bland, et al., 2017).

The second is based on the first strategy of the Nuremberg program: promoting information on signs of depression and the importance of consultation. This systemic deficit was also identified in the New Brunswick study described above. We will focus specifically on mental health literacy programs. These programs already exist in Canada, but in a somewhat circumscribed way; there is no national program to date.

Partners for Life offers an excellent example of successful implementation of such a program. This Quebec initiative, funded by the Mental Illness Foundation (now Fondation Jeunes en Tête), is the largest mental health literacy program in Canada and has reached close to $60 \%$ of high school students in Grades 9 to 11 since its inception, now close to one million teenagers, in a Quebec population of 8 million (Lesage \& 
Moubarac, 2011). Under the program, adolescents receive a standardized 50- to 75-minute presentation, given in a school setting by young adults trained for this purpose, on the warning signs of depression and suicide. They are advised to consult an adult, their teacher, or qualified professionals if they recognize these signs. In ten years of operating the program (1998-2008), the suicide rate among teenagers in Quebec decreased by almost half (Réseau Québécois de Recherche sur le Suicide, 2011). Although a causal link cannot be established on the basis of ecological observations, it is possible to postulate that Partners for Life is partly responsible for this decrease.

This hypothesis is supported by the SEYLE study (Wasserman et al., 2015), a randomized controlled study of 11,100 teenagers in Europe. In this study, mental health literacy programs led to a significant decrease in the number of suicide attempts and severe suicidal ideation at a one-year follow-up compared to the control group, with odds ratios $\mathrm{OR}=0.45, \mathrm{p}=0.014$ for the number of suicide attempts and $\mathrm{OR}=$ $0.50, p=0.025$ for severe suicidal ideation. In the same study, training programs in monitoring for teachers and detection by professionals did not demonstrate any significant difference in the outcomes mentioned. These results suggest that a universal mental health literacy program based on the example of Partners for Life could be beneficial at the national level. Particular attention should therefore be given to evaluating this population strategy in suicide prevention as another intervention that can be generalized to the entire Canadian population.

\section{CONCLUSION}

Suicide is a serious public health problem that hurts 10 Canadians per day, amounting to nearly 3,926 deaths in 2012 (Statistics Canada, 2015). These deaths are preventable. Among the avenues for reducing suicide, improving the quality of services presents an opportunity for the Government of Canada to develop a suicide prevention framework following Parliament's adoption of Bill C-300 (Canada, 2012). However, such an effort must first involve an evaluation of the services' strengths and weaknesses. Many methods for assessing the quality of services exist, such as innovative approaches to audits, the use of administrative databases, and the use of systematized questionnaires. This need to accumulate more data should not, however, delay the evaluation and implementation of other initiatives, such as the development of national mental health literacy programs and increased access to psychotherapy.

\section{REFERENCES}

Afifi, T. O., Enns, M. W., Cox, B. J., Asmundson, G. J, Stein, M. B., \& Sareen, J. (2008). Population attributable fractions of psychiatric disorders and suicide ideation and attempts associated with adverse childhood experiences. American Journal of Public Health, 98(5), 946-952.

Afifi, T. O., Taillieu, T. Zamorski, M. A., Turner, S., Cheung, K., \& Sareen, J. (2016). Association of child abuse exposure with suicidal ideation, suicide plans, and suicide attempts in military personnel and the general population in Canada. JAMA Psychiatry, 73(3), 229-238. doi:10.1001/jamapsychiatry.2015.2732

Bernard, P., Lemay, M., \& Vézina, M. (2004). Perspectives de recherche en santé des populations au moyen de données complexes. Quebec, QC: Institut National de Santé Publique du Québec.

Blais, C., Jean, S., Sirois, C., Rochette, L., Plante, C., Larocque, I. . . Emond, V. (2014). Quebec Integrated Chronic Disease Surveillance System (QICDSS), an innovative approach. Chronic Diseases and Injuries in Canada, 34(4), 226-235. 
Cailhol, L., Pelletier, E., Rochette, L., Laporte, L., David, P., Villeneuve, E. . . Lesage, A. D. (2017). Prevalence, mortality, and health care use among patients with cluster B personality disorders clinically diagnosed in Quebec: A provincial cohort study, 2001-2012. Canadian Journal of Psychiatry, 62(5), 336-342. doi:10.1177/0706743717700818

Canada. (2012). Federal framework for suicide prevention act. S.C. 2012, c. 30.

Chachamovich, E., Kirmayer, L. J., Haggarty, J. M., Cargo, M., McCormick, R., \& Turecki, G. (2015). Suicide among Inuit: Results from a large, epidemiologically representative follow-back study in Nunavut. Canadian Journal of Psychiatry, 60(6), 268-275.

Durkheim, E. (1951). Suicide: A study in sociology (J. A. Spaulding \& G. Simpson, Trans.). Glencoe, IL: Free Press. (Original work published 1897)

Fansi, A., Jehanno, C., Lapalme, M., Drapeau, M., \& Bouchard, S. (2015). Efficacité de la psychothérapie comparativement a la pharmacothérapie dans le traitement des troubles anxieux et dépressifs chez l'adulte : une revue de la littérature. Santé mentale au Québec, 40(4), 141-173.

Hegerl, U., Althaus, D., Schmidtke, A., \& Niklewski, G. (2006). The alliance against depression: 2-year evaluation of a community-based intervention to reduce suicidality. Psychological Medicine, 36(9), 1225-1233.

Hegerl, U., Wittenburg, L., Arensman, E., Van Audenhove, C., Coyne, J. C., \& McDaid, D. (2009). Optimizing suicide prevention programs and their implementation in Europe (OSPI Europe): An evidence-based multilevel approach. BMC Public Health, 9(428). doi:10.1186/1471-2458-9-428

John, A., Dennis, M., Kosnes, L., Gunnell, D., Scourfield, J., Ford, D. V., \& Lloyd, K. (2014). Suicide Information Database-Cymru: A protocol for a population-based, routinely collected data linkage study to explore risks and patterns of healthcare contact prior to suicide to identify opportunities for intervention. BMJ Open, 4(11), e006780. doi:10.1136/bmjopen-2014-006780

Lesage, A. D. (2002). Stratégie de prévention du suicide et données récentes sur le traitement de la dépression : quels obstacles? Revue d'épidemiologie et de santé publique, 50(1), 63-66.

Lesage, A. D., Bland, R., Jonsson, E., Musgrave, I., Kirby, M., \& Vasiliadis H.-M. (2017). Editorial: The case for a federal mental health transition fund. Canadian Journal of Psychiatry, 62(1), 4-7.

Lesage, A. D., \& Moubarac, J.-C. (2011). Solidaires pour la vie, un programme efficace de littératie en santé mentale : analyse et recommandations. Montreal, QC: Réseau Québécois de Recherche sur le Suicide (RQRS).

Lesage, A. D., Séguin, M., Guy, A., Daigle, F., Bayle, M. N., Chawky, N. . . Turecki, G. (2008). Systematic services audit of consecutive suicides in New Brunswick: The case for coordinating specialist mental health and addiction services. Canadian Journal of Psychiatry, 53(10), 671-678.

Lesage, A. D., St-Laurent, D., Gagné, M., \& Légaré, G. (2012). Perspectives de la santé publique pour la prévention du suicide. Santé mentale au Québec, 37(2), 239-255.

Lesage, A. D., Turecki, G., \& Daniels, S. (2017). Letter to the editor: PHAC and a national suicide prevention strategy. Canadian Medical Association Journal, 189(4), E169. doi:10.1503/cmaj.732474

McGirr, A., \& Turecki, G. (2007) The relationship of impulsive aggressiveness to suicidality and other depressionlinked behaviors. Current Psychiatry Reports, 9(6), 460-466.

Navaneelan, T. (2009). Suicide rates: An overview. Health at a Glance. Cat. no. 82-624-X. Ottawa, ON: Statistics Canada. Retrieved from http://www.statcan.gc.ca/pub/82-624-x/2012001/article/11696-eng.htm

Public Health Agency of Canada. (2015). Report from the Canadian Chronic Disease Surveillance System: Mental illness in Canada, 2015. Cat.: HP35-56/2015E-PDF. Ottawa, ON: Author.

Public Health Agency of Canada. (2016). Report from the Canadian Chronic Disease Surveillance System: Mood and anxiety disorders in Canada, 2016. Cat.: HP35-70/2016E-PDF. Ottawa, ON: Author.

Renaud, J., Lesage A. D., St-Laurent, D., Gagné, M., Seguin, M., Boyer, R. . . Turecki, G. (2015). Le suicide. In P. Lalonde \& G.-F. Pinard (Eds.), Psychiatrie clinique : approche bio-psycho-sociale (4th ed): Vol, 2. Spécialités psychiatriques et traitements (pp. 1118-1137). Montreal, QC: Chenelière Éducation.

Renaud, J., Séguin, M., Lesage, A. D., Marquette, C., Choo, B., \& Turecki G. (2014). Service use and unmet needs in youth suicide: A study of trajectories. Canadian Journal of Psychiatry, 59(10), 523-530.

Réseau Québécois de Recherche sur le Suicide (RQRS). (2011). Avis scientifique du RQRS sur le programme Solidaires pour la vie. Récupéré de http://www.fmm-mif.ca/app/webroot/files/AvisScientifiqueSPLV_RQRS_2011.pdf 
Séguin, M., Lesage, A. D., Chawky, N., Guy, A., Daigle, F., Girard, G., \& Turecki, G. (2006). Suicide cases in New Brunswick from April 2002 to May 2003: The importance of better recognizing substance and mood disorder comorbidity. Canadian Journal of Psychiatry, 51(9), 581-586.

Séguin, M., Renaud, J., Lesage, A. D., Robert, M., \& Turecki, G. (2011). Youth and young adult suicide: A study of life trajectory. Journal of Psychiatric Research, 45(7), 863-870.

Statistics Canada. (2015). Suicides and suicide rate, by sex and by age group (both sexes no.). Retrieved from http:// www.statcan.gc.ca/tables-tableaux/sum-som/101/cst01/hlth66a-eng.htm

Sunderland, A., \& Findlay, L. C. (2013). Perceived need for mental health care in Canada: Results from the 2012 Canadian Community Health Survey-Mental Health. Health Reports, 24(9), 3-9.

Thibodeau, L. (2015). Suicide mortality in Canada and Quebec, 1926-2008: An age-period-cohort analysis. Canadian Studies in Population, 42(3-4), 1-23.

Turecki, G., \& Brent, D. (2016). Suicide and suicidal behaviour. Lancet, 387(10024), 1227-1239.

Vasiliadis, H. M., Lesage, A. D., Latimer, E., \& Séguin, M. (2015). Implementing suicide prevention programs: Costs and potential life years saved in Canada. Journal of Mental Health Policy and Economics, 18(3), 147-155.

Wasserman, D., Hoven, C. W., Wasserman, C., Wall, M., Eisenberg, R., Hadlaczky, G. . . Carli, V. (2015). School-based suicide prevention programmes: The SEYLE cluster-randomised, controlled trial. Lancet, 385(9977), 1536-1544.

While, D., Bickley, H, Roscoe, A., Windfuhr, K., Rahman, S., Shaw, J. . . Kapur, N. (2012). Implementation of mental health service recommendations in England and Wales and suicide rates, 1997-2006: A cross-sectional and before-and-after observational study. Lancet, 379(9820), 1005-1012. 


\title{
Perspectives innovatrices pour la prévention du suicide et des possibilités d'actions de l'Agence de santé publique du Canada et du Gouvernement du Canada
}

\author{
Alain Lesage \\ Institut universitaire en santé mentale de Montréal \\ Christophe Tra \\ Université de Montréal \\ Elham Rahme \\ Université McGill \\ Johanne Renaud \\ Institut universitaire en santé mentale Douglas \\ Lise Thibodeau \\ Université McGill \\ Monique Séguin \\ Université du Québec en Outaouais
}

Alain Lesage, chercheur, Centre de recherche, Institut universitaire en santé mentale de Montréal, et professeur titulaire, Département de psychiatrie, Université de Montréal.

Christophe Tra, Université de Montréal; Elham Rahme, Départment de médecine, Division de l'épidémiologie clinique, Université McGill; Johanne Renaud, chercheuse, Centre Manuvie pour les avancées en prévention de la dépression et du suicide chez les jeunes, Institut universitaire en santé mentale Douglas, et professeure agrégée, Département de psychiatrie, Université McGill; Lise Thibodeau, Départment de médecine, Division de l'épidémiologie clinique, Université McGill; Monique Séguin, professeure, Département de psychoéducation et de psychologie, Université du Québec en Outaouais.

La correspondance concernant cet article devrait être acheminée à Alain Lesage, Institut universitaire en santé mentale de Montréal, 7401, rue Hochelaga, Montréal (Québec) H1N 3M5; courriel : alesage.iusmm@ssss.gouv.qc.ca 


\title{
RÉSUMÉ
}

La prévention du suicide est la responsabilité du Gouvernement du Canada et de Santé Canada. Au Canada, la problématique du suicide touche les Canadiens et Canadiennes de tout âge et de toutes les régions du pays, d'où la nécessité d'une stratégie pancanadienne visant la réduction des décès par suicide et touchant tous les Canadiens et Canadiennes. La disponibilité et l'accessibilité des services de santé mentale sont des ressources importantes pour la prévention du suicide et une cible sur laquelle des interventions peuvent être posées pour une réduction rapide du taux de suicide. Une telle stratégie misant sur l'amélioration des services devrait inclure la mise en place de programmes de surveillance et de contrôle de qualité, tels que des programmes d'audits des cas de suicides et l'exploitation des bases de données administratives jumelées gouvernementales. Des stratégies populationnelles de prévention et de traitement de la dépression sont aussi à instaurer, et devraient se baser sur le modèle de Nuremberg. Nous retenons particulièrement prioritaires comme stratégies populationnelles la mise en place de programmes d'accès équitable à la psychothérapie et de littératie en santé mentale.

Mots clés : prévention du suicide, dépendances, dépression, troubles relationnels, services santé mentale et des dépendances, qualité des services, bases de données administratives de santé, système de surveillance des maladies chroniques, audits des suicides

\begin{abstract}
Responsibility for suicide prevention falls to the Government of Canada and Health Canada. The issue of suicide affects Canadians of all ages and in all regions of the country, hence the need for a pan-Canadian strategy aimed at reducing suicide deaths and reaching all Canadians. The availability and accessibility of mental health services constitute important resources for suicide prevention and a target for interventions that can be made to rapidly reduce the suicide rate. Such a strategy to improve services should include quality surveillance and quality control programs, such as suicide audits and the use of linked government administrative databases. Population-based strategies to prevent and treat depression must also be established and should be based on the Nuremberg model. In particular, development of equitable access to psychotherapy and mental health literacy programs should be priority goals.
\end{abstract}

Keywords: suicide prevention, addictions, depression, relationship problems, mental health and addiction services, quality of services, administrative health databases, chronic disease surveillance system, suicide audits

Au Canada, la santé mentale est un sujet d'actualité politique, tant au niveau provincial que fédéral. Les leaders politiques canadiens appellent tous à des investissements en santé mentale, faisant de la prévention du suicide un sujet de premier plan. Or, cette volonté politique doit se traduire par un plan d'action clair et pragmatique, et passe inévitablement par des initiatives de santé publique. Dans le présent essai, nous tentons de présenter des perspectives innovatrices de santé publique pour la prévention du suicide, les rôles que peuvent y occuper les services et des actions que l'Agence de santé publique du Canada et la ministre de la santé pourraient entreprendre.

Dans un premier temps, nous dressons un portrait de l'état du suicide au Canada. Les données présentées permettent de démontrer que le suicide affecte tous les groupes d'âge et toutes les régions du pays. Grâce à ce constat, nous postulons la nécessité d'une stratégie canadienne de prévention du suicide ciblant l'ensemble 
des Canadiens et Canadiennes, non pas seulement les groupes à haut risque. Deuxièmement, nous décrivons des modèles conceptuels permettant de comprendre le suicide d'un point de vue à la fois individuel et systémique. La lecture de ces modèles permet d'identifier les services comme étant une cible prioritaire d'une stratégie nationale de prévention du suicide. Dans un troisième temps, soutenus par la littérature récente et de plus de 30 ans d'expérience en recherche sur les services en santé mentale, nous proposons des interventions innovatrices de santé publique pour la prévention du suicide : (a) la mise en place de moyens d'évaluation des services basés sur une approche bottom-up, dite ascendante, (b) la bonification de la surveillance top-down via l'exploitation des systèmes de surveillance des maladies chroniques, et (c) l'évaluation plus approfondie ou le déploiement de stratégies populationnelles de prévention du suicide, dont les programmes de littératie en santé mentale et l'accès accru à la psychothérapie.

\section{UNE ÉPIDÉMIE SILENCIEUSE QUI ATTEINT TOUS LES CANADIENS ET CANADIENNES}

Au Canada, au début du XXI ${ }^{\mathrm{e}}$ siècle, le suicide est la cause de décès de 10 personnes par jour, soit près de 4000 personnes par année pour un taux de 10,4 par 100000 individus (16,1 pour les hommes et 5,1 pour les femmes) (Navaneelan, 2009). Les hommes de 30 à 60 ans représentent plus de $50 \%$ des cas de suicide et ceux âgés de 45-64 ans sont les plus à risque de suicide avec des taux de près de 25 par 100000 . Pour les jeunes (15-24), le taux est de près de 20 par 100 000, et représentait plus de 200 jeunes Canadiennes et Canadiens entre 15 et 19 ans qui sont morts par suicide en 2010, soit un peu plus de 1 suicide sur 20 survenus au Canada (Thibodeau, 2015; Navaneelan, 2009). Les hommes sont plus atteints que les femmes par le suicide : quatre fois plus d'hommes que de femmes s'enlèvent la vie annuellement (Navaneelan, 2009). La figure 1 indique le nombre de suicides au Canada par province et territoire en 2012. Les Territoires du Nord-Ouest, du Yukon et du Nunavut, où se concentrent des collectivités autochtones, représentent 42 des 3662 cas survenus cette année-là. Cependant, la majorité des suicides viennent du Québec et de l'Ontario : bien que comprenant un peu plus de $25 \%$ de la population canadienne, le Québec déplorait près du tiers des cas de suicide du Canada; si le Québec avait eu le même taux de suicide que l'Ontario, il aurait eu 400 suicides de moins au Québec et au Canada en 2008.

Malgré ce portrait alarmant, les taux de décès par suicide ont diminué au Canada au cours des trois dernières décennies, surtout chez les hommes (Thibodeau, 2015). La figure 2 illustre la diminution des taux dans tous les groupes d'âge et particulièrement chez les adolescents et adolescentes et les personnes âgées. En fait, ce sont chez ces deux groupes que nous observons selon les données les plus récentes les plus bas taux de suicide au pays.

Ces chiffres nous montrent que bien que le taux de suicide soit alarmant dans certains sous-groupes bien connus, tels que les autochtones, l'épidémie du suicide affecte les individus de tout âge et de toutes les régions du Canada, d'où la nécessité d'une stratégie pancanadienne de prévention du suicide devant s'afférer

à mieux comprendre et prévenir l'ensemble des suicides des Canadiens et Canadiennes. Ces chiffres nous suggèrent aussi que certaines stratégies populationnelles ont un potentiel de réduction des taux de suicide. 


\section{Figure 1}

\section{Nombre de suicides au Canada par provinces et territoires, 2012}

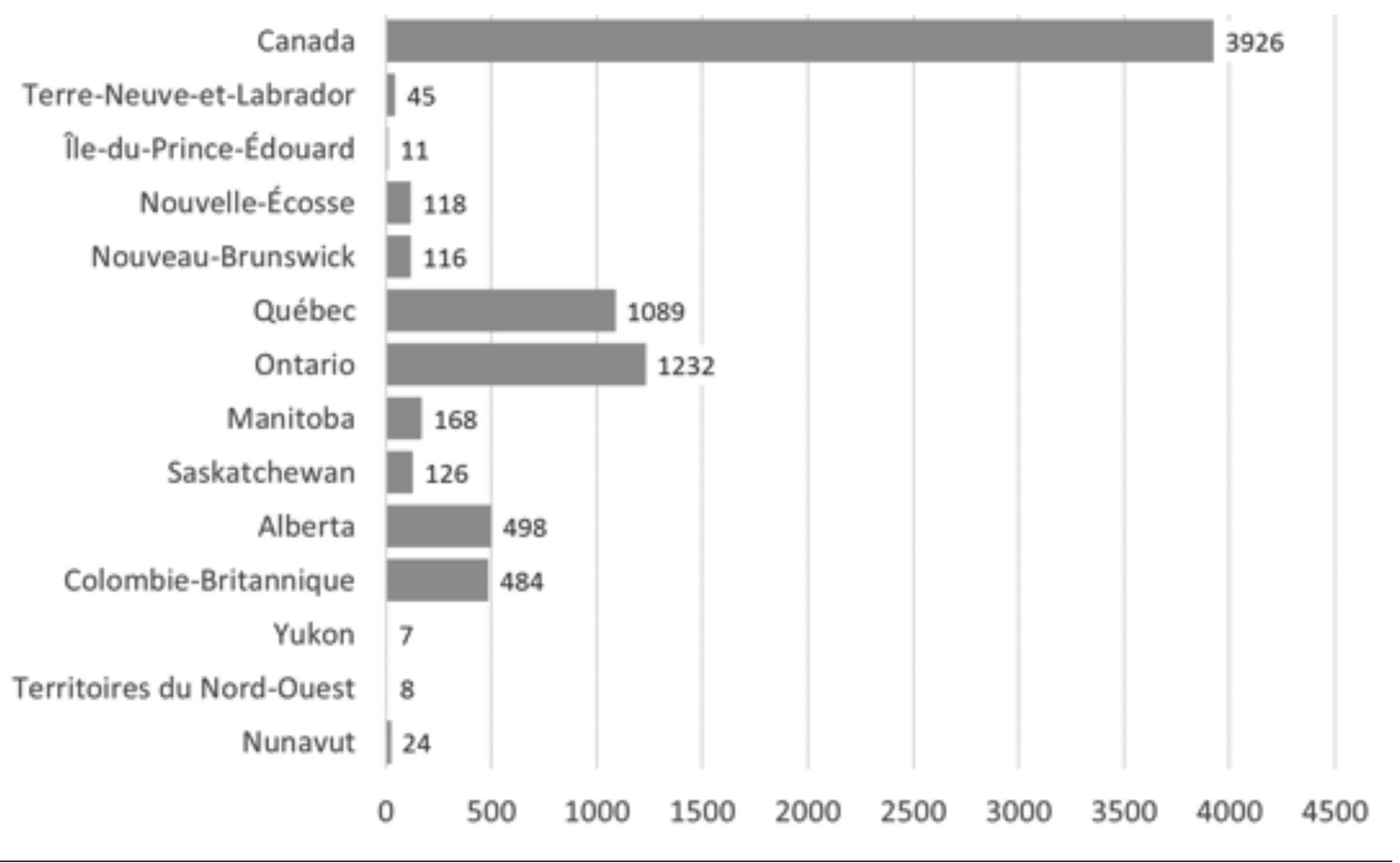

Source : Statistique Canada, Tableau 102-0563, Principales causes de décès, population totale, selon le sexe, Canada, provinces et territoires (normalisation selon l'âge utilisant la population de 1991), récupéré de http://www5. statcan.gc.ca/cansim/a05?lang=fra\&id=1020563\#customizeTab 
Figure 2

Taux de suicide au Canada par groupe d'âges

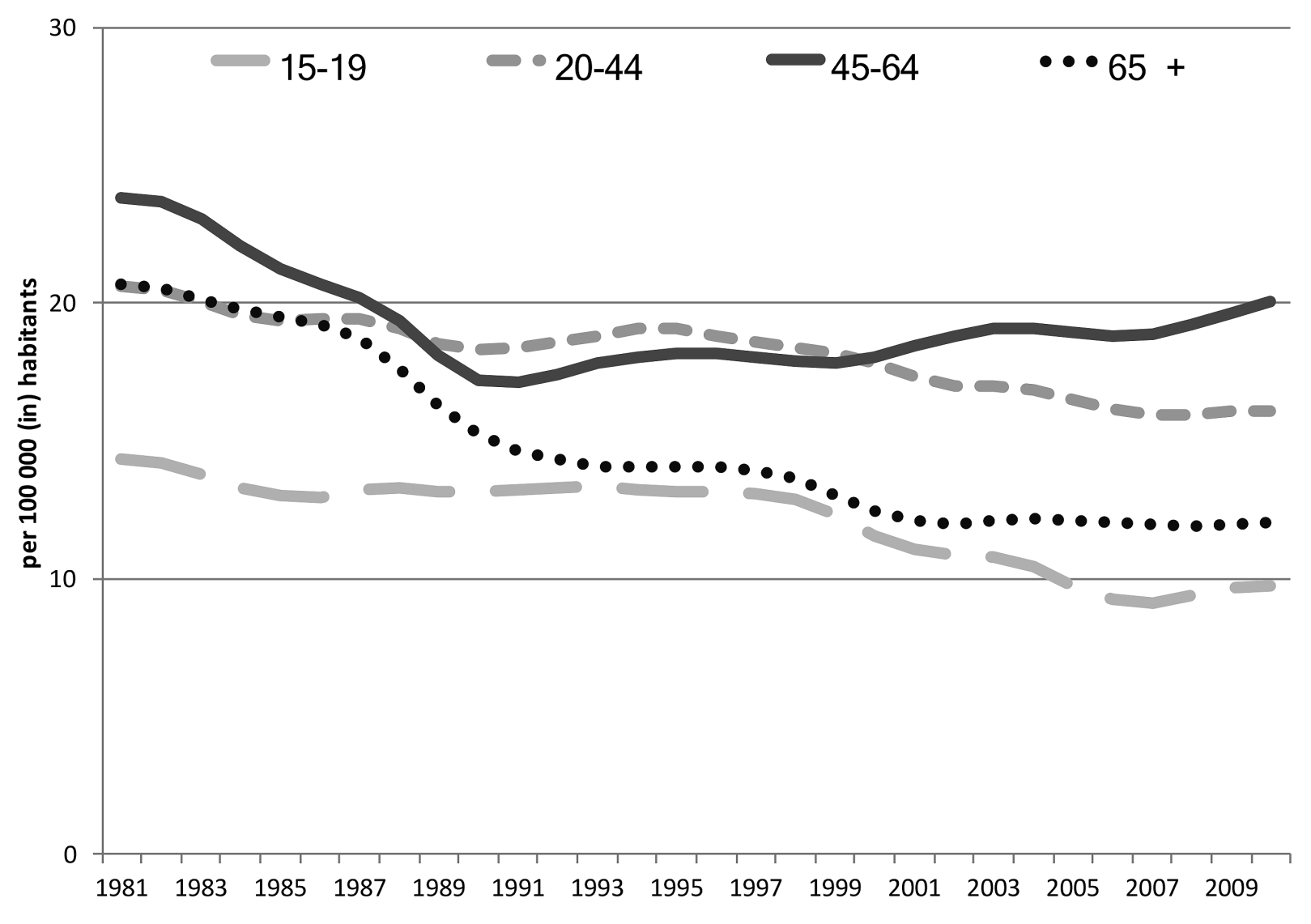

Source : Agence de santé publique du Canada, Institut national de santé publique du Québec 


\section{MODÈLES INDIVIDUELS ET DE SANTÉ PUBLIQUE DE PRÉVENTION DU SUICIDE}

De nombreux modèles théoriques sur la genèse et les déterminants du suicide ont été proposés. Nous retenons ici deux modèles permettant de comprendre le suicide dans une perspective de santé publique.

\section{Modèle causal du suicide des facteurs individuels en contexte social}

Le Groupe McGill d'études sur le suicide a proposé un modèle se penchant sur les causes individuelles du suicide (McGirr et Turecki, 2007; Renaud et al., 2015; Turecki et Brent, 2016) que nous avons redessiné à la figure 3. Des facteurs de prédisposition dont les déterminants biologiques et génétiques, sous l'influence de trauma à l'enfance ou d'évènements adverses de vie, peuvent mener au développement de déterminants médiateurs tels que l'impulsivité ou les troubles de la personnalité. Cette fragilité, en synergie avec le développement de troubles mentaux ou des substances, peut mener au suicide. À noter que ce processus est tout au long modulé par des facteurs extrinsèques à la personne dont les déterminants sociaux. Cette influence de l'environnement social permet de comprendre le suicide dans une perspective de santé publique.

\section{Modèle de santé publique de la qualité des soins en santé mentale}

Cette perspective de santé publique est davantage détaillée par un autre modèle proposé par Lesage, St-Laurent, Gagné et Légaré (2012), basé sur le modèle de l'Institut national de santé publique du Québec (INSPQ) des déterminants de l'état de la santé dans les populations (Bernard, Lemay et Vézina, 2004). Il entrevoyait quatre grands vecteurs : (a) les facteurs génétiques et développementaux, (b) les facteurs environnementaux (physiques ou socioculturels), (c) les habitudes de vie, et finalement (d) les services. Ce modèle est repris dans le cadre conceptuel présenté à la figure 4 qui donne plus d'importance dans la représentation graphique aux services que le modèle précédant comme déterminants en contrepoids aux facteurs plus intrinsèque tels que le sexe, l'âge et l'histoire développementale.

À la lumière de ce modèle, on identifie trois niveaux auxquels les services peuvent influencer le suicide : (a) le niveau individuel (par exemple une psychothérapie qui n'a pas été offerte); (b) le niveau programmatique (par exemple une coordination insuffisante entre les services spécialisés en santé mentale et les services spécialisés en dépendance pour des personnes présentant des comorbidités); et (c) le niveau systémique (par exemple une campagne de sensibilisation à aller consulter si on identifie des signes de dépression ou des problèmes de dépendances aux substances chez soi ou ses proches).

Ces déterminants se rajoutent aux facteurs environnementaux qui existent tant au niveau individuel que populationnel. Par exemple, parmi les facteurs environnementaux sociaux plus macroscopiques se retrouvent le taux de chômage et la défavorisation sociale et matérielle du quartier où demeurait l'individu. De tels déterminants, en particulier l'isolement social, avaient déjà été décrits il y a plus de 100 ans par le fondateur de la sociologie moderne, Émile Durkheim (1897), dans son célèbre livre sur le suicide. Ces facteurs individuels existent aussi dans l'environnement microsocial, par exemple les traumas subis dans l'enfance, tels qu'abordés avec des données américaines et canadiennes par Afifi et al. (Afifi et al., 2008; Afifi et al., 2016). Ils ont montré que la fraction étiologique populationnelle attribuable aux expériences 


\section{Figure 3}

Modèle causal du suicide des facteurs individuels en contexte social
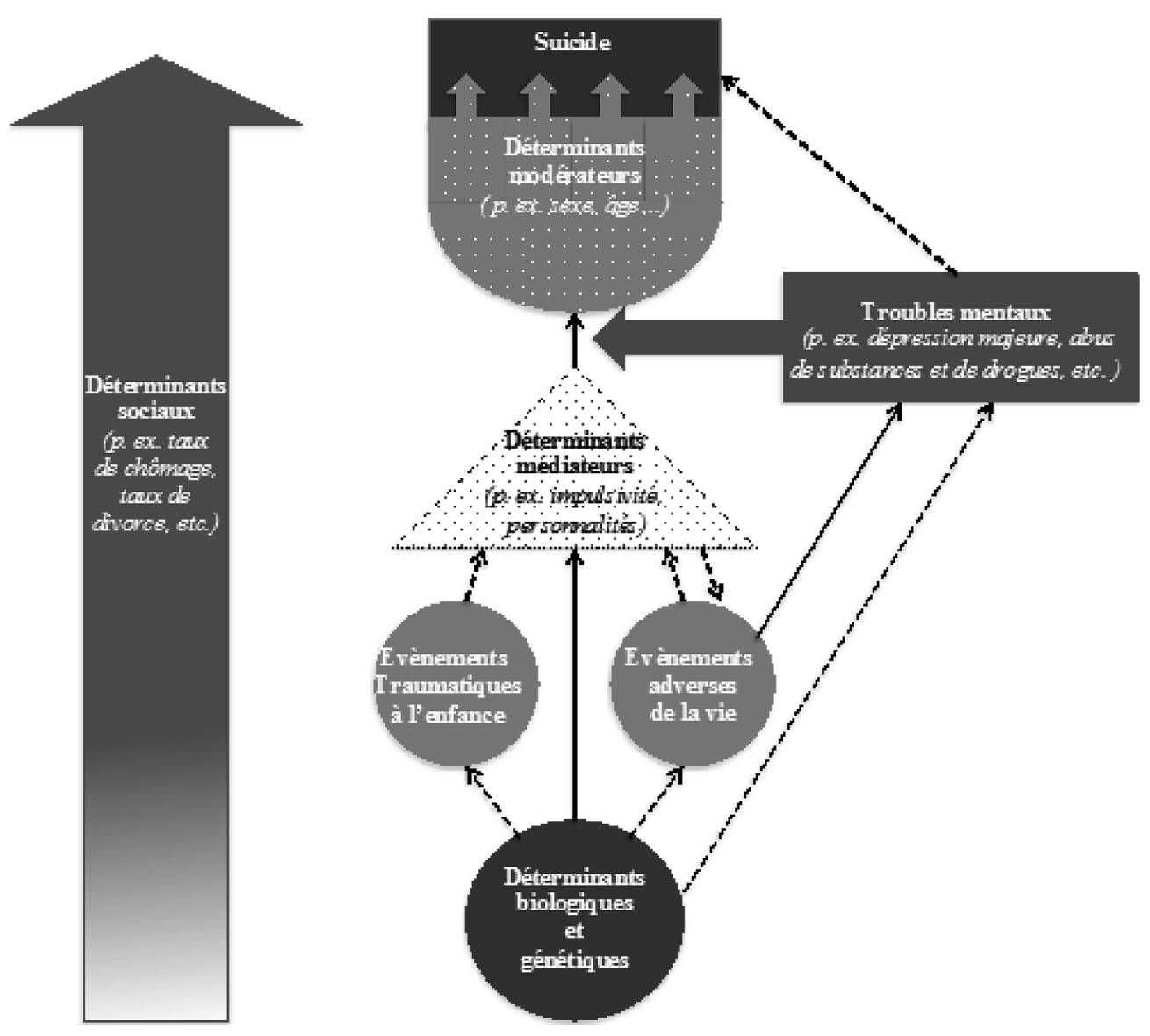


\section{Figure 4}

Modèle de santé publique de la qualité des soins en santé mentale comme un des déterminants environnementaux du suicide dans la population.

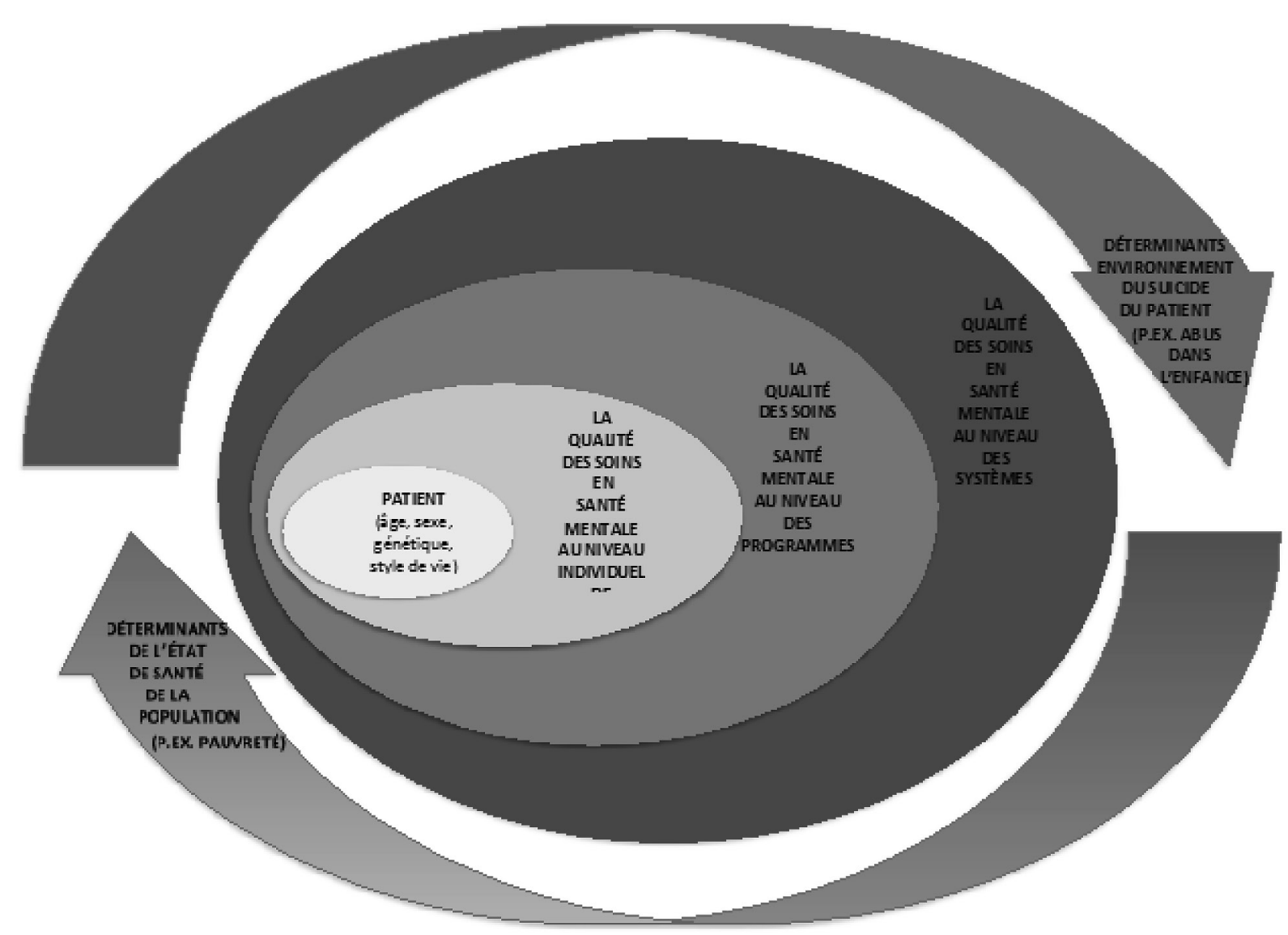


nocives dans l'enfance pour les troubles mentaux, les idéations suicidaires et les tentatives de suicide étaient respectivement de $25 \%, 20 \%$ et $40 \%$.

Ces deux modèles illustrent que le suicide est d'origine multifactorielle et que des interventions peuvent être faites à plusieurs niveaux, à la fois au niveau individuel et systémique. Cependant, dans l'optique d'une stratégie nationale, les facteurs distaux du suicide complété (facteurs génétiques, facteurs développementaux, les traumatismes à l'enfance) se portent moins à des actions de santé publique pouvant mener à une réduction rapide des taux de suicide. Les facteurs plus proximaux, comme la qualité des soins ou une meilleure coordination entre les services des dépendances et les équipes de santé mentale, pourraient offrir des pistes de prévention du suicide avec un impact plus immédiat.

\section{DES SYSTÈMES DE SURVEILLANCE INNOVATEURS}

Nous proposons trois actions que l'Agence de santé publique du Canada et le Gouvernement du Canada devraient mener dans le cadre de leur rôle et de leur responsabilité vis-à-vis la prévention du suicide (Lesage, Turecki et Daniels, 2017) :

1. La mise en place de programmes d'évaluation des services basés sur une approche bottom-up, ou dite ascendante. Nous proposerons ici deux modalités : les programmes d'audit et la mise en place de questionnaires envoyés systématiquement aux médecins traitant de patientes et patients décédés par suicide.

2. La bonification des systèmes de surveillance top-down ou descendante via l'exploitation des systèmes de surveillance des maladies chroniques, comme le Système intégré de surveillance des maladies chroniques du Québec (SISMACQ).

3. L'évaluation plus approfondie et même le déploiement de stratégies populationnelles, dont les programmes de littératie en santé mentale sur le modèle du programme québécois Solidaires pour la vie (aujourd'hui Solidaires pour la santé mentale) et l'accès accru à la psychothérapie.

\section{Les approches ascendantes : les audits}

Les systèmes de surveillance doivent être bonifiés au Canada. Plus de données sont nécessaires à l'évaluation des services en vue de la prévention du suicide au Canada. Une approche ascendante, celle de l'audit, est particulièrement intéressante pour évaluer les forces et lacunes des services. L'audit peut reposer sur un questionnaire envoyé au dernier médecin traitant jusqu'à des entrevues en profondeur connues sous le nom parfois rébarbatif d'autopsies psychologiques.

L'élaboration d'un programme de questionnaires envoyés systématiquement au médecin traitant des patientes et patients décédés par suicide constitue une source intéressante d'information de type ascendante. Un tel programme existe déjà en Grande-Bretagne depuis 1996 pour les patientes et patients connus des services spécialisés psychiatriques qui se sont enlevés la vie, soit $25 \%$ de tous les suicides. Le National Inquiry into Suicide and Homicide by People with Mental Illness collige des questionnaires envoyés aux professionnels et professionnelles responsables regroupant des données sur le patient ou la patiente ainsi que les circonstances entourant le suicide. Grâce à l'enquête menée de façon continue en Grande-Bretagne 
depuis 1996 par un partenariat d'amélioration de la qualité entre le système de santé britannique et les milieux académiques, des recommandations ont été formulées au niveau des programmes régionaux et au niveau du pays. Ces recommandations, par exemple la mise en place de services d'intervention de crise $24 \mathrm{~h}$ ou l'élaboration de politiques pour la gestion des patients et patientes avec double-diagnostics, ont été implantées de façon variable dans les différentes régions. Les régions ayant appliqué les recommandations ont vu leur taux de suicide diminuer (While et al., 2012).

Des méthodes plus élaborées, avec des entrevues en profondeur auprès des familles endeuillées et revue des dossiers médicaux disponibles pour tous les cas de suicide, ont été déployées au Canada dans le cadre d'enquêtes demandées par les gouvernements. Ainsi, au début des années 2000, le gouvernement du Nouveau-Brunswick, préoccupé par les suicides dans sa population, a demandé au Groupe McGill d'études sur le suicide, sous la direction du Dr Monique Séguin, d'examiner tous les cas de suicide survenus au cours d'une année au Nouveau-Brunswick (Lesage et al., 2008).

Dans cette étude au Nouveau-Brunswick en 2003-2004, les méthodes d'autopsie psychologique et d'audit ont alors été employées. Des membres du personnel des centres régionaux de santé mentale ont été formés à réaliser des entrevues semi-structurées par l'équipe de recherche auprès des familles endeuillées et à réviser les dossiers médicaux disponibles. Des histoires de cas tirées d'entrevues familiales et de revues systématiques de dossiers ont été analysées par un panel composé de psychiatres, de psychologues, de représentants et représentantes de la Direction de la santé mentale et des dépendances du ministère de la Santé du Nouveau-Brunswick, de travailleuses et travailleurs sociaux, d'infirmières et d'un représentant ou d'une représentante des familles endeuillées par suicide. Suite à la reconstitution de la trajectoire de vie de chacun des cas, une analyse des services utilisés a été faite et comparée à l'ensemble des services qui auraient dû être offerts selon le panel.

Cette approche innovatrice a d'abord permis de dresser un portrait des trajectoires de vie ayant mené au suicide, et surtout des profils d'utilisation des services : les troubles d'humeur ou des dépendances étaient identifiés dans plus des deux tiers des cas; les troubles de personnalité dans la moitié; et la présence de plus d'un désordre (comorbidité) dans $75 \%$ des cas (Séguin et al., 2006). Les résultats du panel ont ensuite permis d'identifier les déficits des services à plusieurs niveaux. Le tableau 1 compare l'écart selon le panel

Tableau 1

Comparaison entre les interventions reçues et les interventions requises, et le pourcentage d'écart

\begin{tabular}{llll}
\hline & Reçus, $n$ & Requis, $n$ & Écart, \% \\
\hline Médication psychiatrique & 51 & 65 & 22 \\
Milieu résidentiel/hospitalisation/désintox & 38 & 70 & 46 \\
Suivi intensif & 34 & 71 & 52 \\
Psychothérapie & 19 & 48 & 60 \\
Entraide par les pairs & 13 & 12 & - \\
\hline
\end{tabular}

Source : Audit de 102 cas de suicide au Nouveau-Brunswick (Lesage et al., 2008) 
entre les interventions reçues par les personnes au cours de leur dernière année de vie et les interventions requises, de même que le pourcentage d'écart. Ce dernier illustre les déficits possibles dans les services présents au niveau individuel.

Si les besoins de médication psychiatrique étaient généralement bien comblés, on remarque des écarts pour les besoins d'hospitalisation, les services des centres de désintoxication ou pour des suivis plus intensifs. On note d'ailleurs que le besoin le plus largement ignoré était celui de counselling ou de psychothérapie. Les résultats démontrent que dans près de $30 \%$ des cas, aucune recommandation ne pouvait être apportée, mais que dans plus de $70 \%$ des cas émergeaient deux grands patrons de déficits dans les programmes et le système de santé. Dans presque la moitié de ces cas, il y avait des besoins non comblés au niveau des services sociaux et de santé primaires puisque les individus ne savaient pas auprès de qui faire des demandes d'aide. Il serait possible de répondre à ces besoins à travers les actions suivantes : campagnes populationnelles pour encourager les gens à aller consulter pour les problèmes de santé mentale ou de dépendance, plus de formation des médecins de famille et des intervenantes et intervenants psychosociaux de première ligne à l'accueil, l'identification et le traitement des troubles mentaux et des dépendances et, si nécessaire, l'orientation vers les services spécialisés.

Le deuxième grand type de recommandations portait sur le besoin de coordination et de continuité entre les services spécialisés de santé mentale, les services de dépendances, les services des urgences hospitalières et parfois la collaboration avec les services de justice. Ces services auraient pu bénéficier d'une approche plus proactive et plus collaborative et de liaisons serrées entre les secteurs nommés précédemment (Lesage et al., 2008).

Des études utilisant la même approche chez les adolescents et adolescentes et les jeunes adultes ont été conduites sous la direction du Dr Johanne Renaud. Ainsi, des études de cas témoins ont été menées chez 67 jeunes (Séguin, Renaud, Lesage, Robert et Turecki, 2011; Renaud et al., 2014). Durant la dernière année de leur vie, ces jeunes de 14 à 25 ans décédés par suicide avaient 8 à 63 fois plus de risque de présenter des troubles dépressifs, d'anxiété ou de dépendance aux substances que les jeunes du groupe témoin. L'examen de leur trajectoire de vie entre 0 et 4 ans indiquait que $50 \%$ de ces jeunes avaient été exposés à la violence ou l'abus physique ou sexuel. Ceci atteignait $60 \%$ entre 5 et 9 ans et $67 \%$ entre 10 et 14 ans. Pour les jeunes du groupe témoin cela n'atteignait respectivement que $14 \%, 18 \%$ et $34 \%$.

Deux grands types de trajectoires de suicide étaient distingués. Le premier groupe se caractérise par une adversité débutant très tôt dans la vie, associée à des facteurs développementaux et environnementaux qui favorisent un état de vulnérabilité à la présence de troubles mentaux. Ces jeunes deviendront très bien connus des services spécialisés jeunesse, de santé mentale ou des dépendances. Le second groupe se caractérise par la présence plus tardive d'adversité, davantage associées aux habitudes de vie et présentant moins de comorbidités. Ces patientes et patients étaient donc plutôt suivis par les services sociaux et de santé primaires. Une analyse détaillée de l'organisation des services auprès de ces jeunes a également démontré des déficits significatifs comparables à ceux de l'étude du Nouveau-Brunswick.

De plus, des facteurs de risque similaires ont été identifiés dans une étude chez les Inuits (Chachamovich et al., 2015). Les entrevues ont été menées auprès de leurs proches et ont permis de reconstruire la trajectoire de vie, en recherchant les adversités, les troubles mentaux et les traits d'impulsivité et d'agressivité. Les 
résultats montrent que les personnes décédées par suicide étaient plus à même d'avoir vécu des expériences d'abus physiques et sexuels dans l'enfance, d'avoir connu la dépression et la dépendance à l'alcool et au cannabis, d'avoir plus de traits d'impulsivité et d'agressivité et de présenter des troubles de la personnalité.

Ainsi, notre recommandation à l'endroit de l'Agence de santé publique du Canada serait de créer, comme au Royaume-Uni, une enquête confidentielle sur tous les cas de suicide, en adoptant soit la stratégie des questionnaires aux derniers médecins traitants ou celle des entrevues avec les familles endeuillées ou une combinaison des deux, en vue d'établir des pistes de solution à l'amélioration des services pour tous les Canadiens et Canadiennes. On peut espérer que, comme en Grande-Bretagne, en suivant ces recommandations les taux de suicide diminueront dans toutes les communautés canadiennes.

\section{LES APPROCHES DESCENDANTES : LES BASES DE DONNÉES ADMINISTRATIVES}

L'examen des bases de données administratives de santé peut aussi être révélateur de déficits. Au pays de Galles, la santé publique en collaboration avec les milieux académiques a mis en place une plate-forme d'examen des bases de données administratives jumelées regroupant les données sur la santé des populations pour dépister effectivement les déficits dans les services (John et al., 2014). Le Canada possède lui aussi un système similaire. Le système de surveillance des maladies chroniques de l'Agence de santé publique du Canada reçoit des données agrégées de chacune des provinces et lui permet de suivre l'évolution des indicateurs de qualité des services médicaux aux fins de santé mentale. Deux rapports ont déjà été produits pour les troubles mentaux en général et pour les troubles anxio-dépressifs (Agence de la santé publique du Canada, 2015, 2016). Au Québec, une analyse produite avec le Système intégré de surveillance des maladies chroniques du Québec (Blais et al., 2014) a permis d'examiner l'utilisation des services dans l'année précédant le décès. Le résultat est présenté dans le tableau 2. On constate dans l'année précédant leur décès que plus de la moitié des personnes décédées par suicide avait fréquenté l'urgence; $30 \%$ avait consulté des psychiatres en ambulatoire; et plus de $80 \%$, des médecins de famille, même si seulement la moitié avait été formellement identifiée avec un trouble mental ou des dépendances lors de ce contact avec les médecins de famille.

Dans une publication récente, l'Institut national de santé publique du Québec a montré en utilisant les données du SISMACQ que les individus atteints de troubles de la personnalité ont une espérance de vie réduite de plus de 12 ans en moyenne et que le quart des décès étaient dûs au suicide. De plus, ces individus faisaient une plus grande utilisation de l'urgence et des services spécialisés (Cailhol et al., 2017). Ces résultats obtenus avec une large base de données administratives en santé complémentent ceux des audits pour soutenir l'importance de la coordination entre les services des urgences et les services spécialisés de santé mentale pour les personnes présentant des troubles de la personnalité.

La mise en place d'outils de surveillance en contexte canadien — soit à travers des audits à l'aide de questionnaires aux médecins ou des entrevues en profondeur avec les familles pour établir la trajectoire de vie de la personne et les besoins non comblés de services, soit via l'analyse des banques de données administratives jumelées - représente une opportunité innovatrice à l'échelle nationale pour mieux identifier les déficits dans les services, faire des recommandations ciblées et espérer leur mise en place aux niveaux 


\section{Tableau 2}

Utilisation des services médicaux dans l'année précédant le décès par 12301 cas de suicide au Québec 2000-2009

\begin{tabular}{ll}
\hline Aux fins de santé mentale (diagnostic santé mentale associé au service) : \\
\hline Hospitalisation & $14 \%$ \\
Urgence & $27 \%$ \\
Psychiatre en ambulatoire & $31 \%$ \\
Omnipraticien(ne) en ambulatoire & $45 \%$ \\
Aucun contact pour fins apparentes de santé mentale & $47 \%$ \\
\hline Tout contact avec les services médicaux : & \\
\hline Hospitalisation & $27 \%$ \\
Urgence & circa $49 \%$ \\
Omnipraticien(ne) & entre $79 \%$ et $86 \%$ \\
Spécialiste & entre $72 \%$ et $76 \%$ \\
Aucun contact & entre $12 \%$ et $21 \%$ \\
\hline
\end{tabular}

Source : Unité de surveillance des maladies chroniques et de leurs déterminants, INSPQ; RAMQ, MeDEcho, Institut de la statistique du Québec

provincial, régional, des programmes et dans la pratique individuelle pour ultimement réduire le nombre de décès par suicide.

\section{Le déploiement de stratégies populationnelles de prévention du suicide par le meilleur traitement de la dépression}

Les études ascendantes comme celles au Nouveau-Brunswick ont confirmé la fraction populationnelle importante attribuable à la dépression et l'importance d'une stratégie populationnelle de prévention du suicide (Lesage, 2002). Il s'agit d'assurer (a) que la population soit en mesure d'identifier les signes et les symptômes lorsqu'une personne ou son proche souffre de dépression et consulter, et (b) que des traitements efficaces soient offerts dans un contexte de soins sociaux et de santé primaires. Le programme de stratégies populationnelles du meilleur traitement de la dépression le plus connu et étudié est celui développé à Nuremberg et étendu dans plusieurs pays européens (Hegerl, Althaus, Schmidtke et Niklewski, 2006; Hegerl et al., 2009). Il repose sur quatre stratégies : (a) campagnes publiques de sensibilisation à l'identification de la dépression et au fait qu'elle peut être traitée; (b) formation des médecins de famille à la détection et la gestion thérapeutique de la dépression et des risques suicidaires; (c) formation des intervenantes et intervenants psychosociaux de première ligne à la détection et la gestion thérapeutique de la dépression et des risques suicidaires; et (d) amélioration de la gestion thérapeutique des personnes à risque connu, par exemple celles se présentant dans les urgences suite à une tentative suicidaire. 
Ce programme soutient pouvoir réduire les taux de suicide du quart. Tenant compte du contexte canadien, un groupe de chercheurs a modélisé les coûts et les bénéfices de déployer ce programme et ses quatre stratégies populationnelles (Vasiliadis, Lesage, Latimer et Séguin, 2015). Avec un potentiel de réduction du suicide de $25 \%$, le programme s'autofinancerait, étant peu coûteux : environ 3 \$ per capita par année, alors que le budget de santé mentale québécois est environ de 170 \$ par habitant. Le budget de la santé et des services sociaux, sans le paiement des médecins et des médicaments, est de 2500 \$ par habitant.

D'autre part, deux volets en particulier pourraient être rapidement déployés par le ministère de la santé fédéral : (a) l'accès accru à la psychothérapie dans le cadre du fonds fédéral de transition en santé mentale (Lesage, Bland et al., 2017) et (b) l'évaluation pour l'extension du programme de littératie en santé mentale Solidaires pour la vie (Lesage et Moubarac, 2011).

Le premier repose sur la constatation d'un déficit énorme de counselling trouvé dans $60 \%$ des cas de suicide au Nouveau-Brunswick (voir tableau 1). La psychothérapie est un traitement efficace de la dépression (Fansi, Jehanno, Lapalme, Drapeau et Bouchard, 2015) qui complèterait bien l'offre de service des médecins de famille qui la prescriraient. Au Canada, plus de $12 \%$ de la population adulte a exprimé un besoin de thérapie, et dans le tiers des cas, ce besoin était non comblé (Sunderland et Findlay, 2013). En Australie, la psychothérapie prescrite par un médecin de famille et faite par un psychologue certifié lui est remboursé par l'assurance-maladie publique, comme la RAMQ au Québec ou L'Assurance-santé de l'Ontario (Lesage, Bland et al., 2017).

La seconde repose sur la première stratégie du programme Nuremberg, celle de promotion informant sur les signes de la dépression et l'importance de consulter. Ce déficit systémique avait aussi été identifié dans l'étude du Nouveau-Brunswick décrite plus haut. Nous nous pencherons plus particulièrement sur les programmes de littératie en santé mentale. Ces programmes existent déjà au Canada, mais de façon plutôt circonscrite. Aucun programme à l'échelle nationale n'existe encore.

Solidaires pour la vie est un bel exemple de réussite d'implantation d'un tel programme. Cette initiative québécoise, financée par la Fondation des maladies mentales (aujourd'hui la Fondation jeunes en tête), est le plus grand programme de littératie en santé mentale au Canada et a rejoint près de $60 \%$ des élèves de secondaire III à V ( $9^{\mathrm{e}}$ à $11^{\mathrm{e}}$ année) depuis ses débuts, soit près maintenant d'un million d'adolescents et adolescentes alors que le Québec compte 8 millions d'habitants (Lesage et Moubarac, 2011). Les adolescents et adolescentes reçoivent une présentation standardisée de 50 à 75 minutes, donnée en milieu scolaire par de jeunes adultes formés à cet effet, sur les signes d'alarme de la dépression et du suicide. Ils sont invités à consulter un adulte, leur professeur ou des professionnelles et professionnels qualifiés lorsque ces signes sont reconnus. En 10 ans d'activités (1998-2008), le taux de suicide chez les adolescentes et adolescents québécois a diminué de près de moitié (Réseau québécois de recherche sur le suicide, 2011). Quoique le lien de causalité ne puisse être établi sur la base d'observations écologiques, il nous est toutefois possible de postuler que Solidaires pour la vie est en partie responsable de cette diminution.

Cette hypothèse est supportée par l'étude SEYLE (Wasserman et al., 2015), une étude randomisée contrôlée portant sur 11100 adolescentes et adolescents européens. Dans cette étude, les programmes de littératie en santé mentale ont démontré une diminution significative du nombre de tentatives de suicide et des idéations suicidaires sévères à un suivi d'un an par rapport au groupe témoin, avec des ratios de cotes 
$O R=0,45, p=0,014$ pour le nombre de tentatives de suicide et $O R=0,50, p=0,025$ pour les idéations suicidaires sévères. Dans cette même étude, les programmes de formation sentinelle auprès des professeurs et le dépistage par des professionnels et professionnelles n'ont pas démontré de différence significative sur les issues mentionnées. Ces résultats suggèrent qu'un programme universel de littératie en santé mentale basé sur l'exemple de Solidaires pour la vie pourrait être bénéfique à l'échelle nationale. Une attention particulière devrait donc être portée à l'évaluation de cette stratégie populationnelle en prévention du suicide comme une autre intervention généralisable à l'ensemble de la population canadienne.

\section{CONCLUSION}

Le suicide est une problématique grave de santé publique qui fauche 10 Canadiens et Canadiennes par jour, près de 3926 décès en 2012 (Statistique Canada, 2015). Ces décès sont évitables, et parmi les pistes de réduction du suicide, l'amélioration de la qualité des services présente une opportunité à saisir par le gouvernement du Canada dans l'obligation de développer un cadre de prévention du suicide suite à l'adoption de la loi C-300 (Canada, 2012) par le Parlement du Canada. Or, cette amélioration des services doit tout d'abord passer par une identification de ses forces et de ses lacunes. De nombreuses méthodes d'évaluation de la qualité des services existent, par exemple les approches innovatrices des audits, de l'exploitation des bases de données administratives et de l'utilisation de questionnaires systématisés. Cette nécessité d'accumuler plus de données ne devrait toutefois pas retarder l'évaluation et l'implantation d'autres initiatives, par exemple la mise en place de programmes nationaux de littératie en santé mentale et l'accès accru à la psychothérapie.

\section{RÉFÉRENCES}

Afifi, T. O., Enns, M. W., Cox, B. J., Asmundson, G. J, Stein, M. B. et Sareen, J. (2008). Population attributable fractions of psychiatric disorders and suicide ideation and attempts associated with adverse childhood experiences. American Journal of Public Health, 98(5), 946-952.

Afifi, T. O., Taillieu, T. Zamorski, M. A., Turner, S., Cheung, K. et Sareen, J. (2016). Association of child abuse exposure with suicidal ideation, suicide plans, and suicide attempts in military personnel and the general population in Canada. JAMA Psychiatry, 73(3), 229-238. doi:10.1001/jamapsychiatry.2015.2732

Agence de la santé publique du Canada. (2015). Rapport du Système canadien de surveillance des maladies chroniques : Les maladies mentales au Canada, 2015. Cat.: HP35-56/2015F-PDF. Ottawa, ON : Auteur.

Agence de la santé publique du Canada. (2016). Rapport du Système canadien de surveillance des maladies chroniques : Les troubles anxieux et de l'humeur au Canada, 2016. Cat.: HP35-70/2016F-PDF. Ottawa, ON : Auteur.

Bernard, P., Lemay, M. et Vézina, M. (2004). Perspectives de recherche en santé des populations au moyen de données complexes. Québec, QC : Institut national de santé publique du Québec.

Blais, C., Jean, S., Sirois, C., Rochette, L., Plante, C., Larocque, I. [. . .] Emond, V. (2014). Quebec Integrated Chronic Disease Surveillance System (QICDSS), an innovative approach. Chronic Diseases and Injuries in Canada, 34(4), 226-235.

Cailhol, L., Pelletier, E., Rochette, L., Laporte, L., David, P., Villeneuve, E. [. . .] Lesage, A. D. (2017). Prevalence, mortality, and health care use among patients with cluster B personality disorders clinically diagnosed in Quebec: A provincial cohort study, 2001-2012. Revue canadienne de psychiatrie, 62(5), 336-342. doi:10.1177/0706743717700818

Canada. (2012). Loi sur le cadre fédéral de prévention du suicide. L.C. 2012, ch. 30.

Chachamovich, E., Kirmayer, L. J., Haggarty, J. M., Cargo, M., McCormick, R. et Turecki, G. (2015). Suicide among Inuit: Results from a large, epidemiologically representative follow-back study in Nunavut. Revue canadienne de psychiatrie, 60(6), 268-275.

Durkheim, E. (1897). Le suicide : étude de sociologie. Paris, France : Félix Alcan. 
Fansi, A., Jehanno, C., Lapalme, M., Drapeau, M. et Bouchard, S. (2015). Efficacité de la psychothérapie comparativement a la pharmacothérapie dans le traitement des troubles anxieux et dépressifs chez l'adulte : une revue de la littérature. Santé mentale au Québec, 40(4), 141-173.

Hegerl, U., Althaus, D., Schmidtke, A. et Niklewski, G. (2006). The alliance against depression: 2-year evaluation of a community-based intervention to reduce suicidality. Psychological Medicine, 36(9), 1225-1233.

Hegerl, U., Wittenburg, L., Arensman, E., Van Audenhove, C., Coyne, J. C. et McDaid, D. (2009). Optimizing suicide prevention programs and their implementation in Europe (OSPI Europe): An evidence-based multilevel approach. BMC Public Health, 9(428). doi:10.1186/1471-2458-9-428

John, A., Dennis, M., Kosnes, L., Gunnell, D., Scourfield, J., Ford, D. V. et Lloyd, K. (2014). Suicide Information Database-Cymru: A protocol for a population-based, routinely collected data linkage study to explore risks and patterns of healthcare contact prior to suicide to identify opportunities for intervention. BMJ Open, 4(11), e006780. doi:10.1136/bmjopen-2014-006780

Lesage, A. D. (2002). Stratégie de prévention du suicide et données récentes sur le traitement de la dépression : quels obstacles? Revue d'épidemiologie et de santé publique, 50(1), 63-66.

Lesage, A. D., Bland, R., Jonsson, E., Musgrave, I., Kirby, M. et Vasiliadis H.-M. (2017). Editorial: The case for a federal mental health transition fund. Revue canadienne de psychiatrie, 62(1), 4-7.

Lesage, A. D. et Moubarac, J.-C. (2011). Solidaires pour la vie, un programme efficace de littératie en santé mentale: analyse et recommandations. Montréal, QC : Réseau québécois de recherche sur le suicide (RQRS).

Lesage, A. D., Séguin, M., Guy, A., Daigle, F., Bayle, M. N., Chawky, N. [. . .] Turecki, G. (2008). Systematic services audit of consecutive suicides in New Brunswick: The case for coordinating specialist mental health and addiction services. Revue canadienne de psychiatrie, 53(10), 671-678.

Lesage, A. D., St-Laurent, D., Gagné, M. et Légaré, G. (2012). Perspectives de la santé publique pour la prévention du suicide. Santé mentale au Québec, 37(2), 239-255.

Lesage, A. D., Turecki, G. et Daniels, S. (2017). Letter to the editor: PHAC and a national suicide prevention strategy. Canadian Medical Association Journal, 189(4), E169. doi:10.1503/cmaj.732474

McGirr, A. et Turecki, G. (2007) The relationship of impulsive aggressiveness to suicidality and other depression-linked behaviors. Current Psychiatry Reports, 9(6), 460-466.

Navaneelan, T. (2009). Les taux de suicide : un aperçu. Coup d'œil sur la santé. Cat. no 82-624-X. Ottawa, ON : Statistique Canada. Récupéré de http://www.statcan.gc.ca/pub/82-624-x/2012001/article/11696-fra.htm

Renaud, J., Lesage A. D., St-Laurent, D., Gagné, M., Seguin, M., Boyer, R. [. . .] Turecki, G. (2015). Le suicide. Dans P. Lalonde et G.-F. Pinard (dir.), Psychiatrie clinique : approche bio-psycho-sociale (4éd) : Tome 2. Spécialités psychiatriques et traitements (p. 1118-1137). Montréal, QC : Chenelière Éducation.

Renaud, J., Séguin, M., Lesage, A. D., Marquette, C., Choo, B. et Turecki G. (2014). Service use and unmet needs in youth suicide: A study of trajectories. Revue canadienne de psychiatrie, 59(10), 523-530.

Réseau québécois de recherche sur le suicide (RQRS). (2011). Avis scientifique du RQRS sur le programme Solidaires pour la vie. Récupéré de http://www.fmm-mif.ca/app/webroot/files/AvisScientifiqueSPLV_RQRS_2011.pdf

Séguin, M., Lesage, A. D., Chawky, N., Guy, A., Daigle, F., Girard, G. et Turecki, G. (2006). Suicide cases in New Brunswick from April 2002 to May 2003: The importance of better recognizing substance and mood disorder comorbidity. Revue canadienne de psychiatrie, 51(9), 581-586.

Séguin, M., Renaud, J., Lesage, A. D., Robert, M. et Turecki, G. (2011). Youth and young adult suicide: A study of life trajectory. Journal of Psychiatric Research, 45(7), 863-870.

Statistique Canada. (2015). Suicides et taux de suicide selon le sexe et l'âge (nombres pour les deux sexes). Récupéré de http://www.statcan.gc.ca/tables-tableaux/sum-som/102/cst01/hlth66a-fra.htm

Sunderland, A. et Findlay, L. C. (2013). Perceived need for mental health care in Canada: Results from the 2012 Canadian Community Health Survey-Mental Health. Health Reports, 24(9), 3-9.

Thibodeau, L. (2015). Suicide mortality in Canada and Quebec, 1926-2008: An age-period-cohort analysis. Canadian Studies in Population, 42(3-4), 1-23.

Turecki, G. et Brent, D. (2016). Suicide and suicidal behaviour. Lancet, 387(10024), 1227-1239.

Vasiliadis, H. M., Lesage, A. D., Latimer, E. et Séguin, M. (2015). Implementing suicide prevention programs: Costs and potential life years saved in Canada. Journal of Mental Health Policy and Economics, 18(3), 147-155. 
Wasserman, D., Hoven, C. W., Wasserman, C., Wall, M., Eisenberg, R., Hadlaczky, G. [. . .] Carli, V. (2015). School-based suicide prevention programmes: The SEYLE cluster-randomised, controlled trial. Lancet, 385(9977), 1536-1544.

While, D., Bickley, H, Roscoe, A., Windfuhr, K., Rahman, S., Shaw, J. [. . .] Kapur, N. (2012). Implementation of mental health service recommendations in England and Wales and suicide rates, 1997-2006: A cross-sectional and before-and-after observational study. Lancet, 379(9820), 1005-1012. 